\title{
Studies of linkage in populations. XIII. A unique cause of linkage disequilibrium in natural populations of Drosophila robusta
}

\author{
MAX LEVITAN $\dagger^{*} \&$ WILLIAM J . ETGES $\$$ \\ $\dagger$ †Departments of Cell Biology/Anatomy and Human Genetics, Mt Sinai School of Medicine of the City University of \\ New York, New York, New York 10029, and łDepartment of Biological Sciences, University of Arkansas, Fayetteville, \\ Arkansas 72701, U.S.A.
}

\begin{abstract}
Natural populations of Drosophila robusta are polymorphic for chromosomal gene arrangements in most of its range, the deciduous forests of North America east of the Rocky Mountains. Many of the gene arrangements are the result of paracentric inversions on both arms of the metacentric second chromosome. They are frequently in linkage disequilibrium, determined in many areas largely, or entirely, by differing frequencies of cis and trans forms of the double heterokaryotypes and their component linkage combinations. Presence and degree of linkage disequilibrium in these populations varies with locality and gender, with males from southern localities exhibiting the largest deviation from equilibrium. Analysis of the extensive karyotype data encompassing the entire species range collected over the past 50 years shows that natural selection is primarily responsible for maintaining these complex polymorphisms.
\end{abstract}

Keywords: Drosophila robusta, inversion polymorphism, karyotypes, linkage disequilibrium, natural selection.

\section{Introduction}

A few years after T. H. Morgan and his co-workers established some of the first linkage groups in Drosophila, Robbins (1918) demonstrated mathematically that, in a population, in the absence of selection, any two loci, whether independent or linked, should, over time, exist in random equilibrium if there is any recombination between them; that is, the frequency of their combination should be equal to the product of their individual frequencies. The degree of recombination would only determine the number of generations needed to reach equilibrium, so that independent loci or syntenic genes that are very far apart would reach equilibrium faster than genes that are closely linked, but the eventual result would be the same. Geiringer (1944, 1948) extended the theory to multiple alleles and loci that recombine at different rates in the two sexes.

Linkage disequilibrium between gene arrangements on the same chromosome is not uncommon in Drosophila and other insects (Levitan \& Fukatami, 1993), yet in most cases data are lacking concerning the

*Correspondence. E-mail: MAX_LEVITAN@smtplink.mssm.edu maintenance of the disequilibrium. Drosophila robusta is an especially valuable species in this regard, because most selectively neutral explanations, such as low recombination rates, genetic drift, gene flow among structured populations and longterm population genetic fluctuations, have been discarded. Recombination rates between linked gene arrangements are variable and respond to the karyotypic background (Levitan, 1958a), reaching almost $50 \%$ under some circumstances, so the absence of recombination cannot be responsible. For both the $\mathrm{X}$ and second chromosomes, frequencies of linked gene arrangements on opposite chromosomal arms respond similarly to elevation in widely separated localities (Levitan, 1978; Levitan \& Scheffer, 1993), and those of the $\mathrm{X}$ chromosome cycle seasonally in some populations (Levitan, 1992). Although overwintering and other causes of mortality leading to population bottlenecks remain unstudied in $D$. robusta, parallel altitudinal clines suggest that the form of linkage is selectively maintained and not an artifact of small population size or gene flow between structured populations. Gene arrangement frequencies are extremely static in some populations (Carson, 1958), and linked gene arrangements show evidence of concerted long-term shifts in other 
populations (Etges, 1984; Levitan, 1992). Even if different recombination rates between cis and trans double heterozygotes were to generate some linkage disequilibrium (Turelli et al., 1984), this source of linkage cannot explain parallel geographical clines. Thus, linkage disequilibrium is a long-standing hallmark of adaptation in natural populations of $D$. robusta rather than a short-term consequence of low recombination rates and slow decay of linkage in non-equilibrium populations

Carson \& Stalker (1947) named the four common gene arrangements on the left arm of the second chromosome in D. robusta populations $2 \mathrm{~L}$ (the so-called standard), $2 \mathrm{~L}-1,2 \mathrm{~L}-2$ and $2 \mathrm{~L}-3$, and the two on the right arm $2 \mathrm{R}$ (standard) and $2 \mathrm{R}-1$. In short-hand notation, these are called S, 1, 2 and 3 on the left and $\mathrm{S}$ and 1 on the right. Linkage haplotypes are labelled accordingly: $2 \mathrm{~L} .2 \mathrm{R}=S S$, $2 \mathrm{~L}-1.2 \mathrm{R}=1 \mathrm{~S}$, etc. The arrangements differ from the standard of each arm by paracentric inversions. As there is almost no recombination between loci trapped between the breakpoints of each inversion, the arrangements can be thought of as allelic blocks.

This report documents the maintenance of second chromosome disequilibria caused by the cis and trans double heterokaryotypes in the light of considerable additional data from natural populations.

\section{Materials and methods}

The data are derived from karyotypic analyses of adult males and females by the methods described by Levitan (1955). In short, adults were trapped over fermenting bananas and returned to the laboratory. The females were placed in individual food vials or bottles and transferred periodically until depleted of sperm. Each male was immediately mated to a stock, homokaryotypic female, and sperm-depleted females were mated to stock males. At least six $F_{1}$ from each cross were scored to infer the karyotype of each adult.

The four widespread left arm arrangements of $D$. robusta can be combined in 10 ways, and the two right arrangements in three ways, for a total of 30 different karyotypes. Levitan (1955) found 28 of the 30 in 2160 flies from two woods near Blacksburg, Montgomery County, VA, U.S.A., and their observed numbers fitted closely with equilibrium expectatations based on the arrangement frequencies $\left(\chi_{16}^{2}=23.2\right)$. When, however, the six kinds of double heterokaryotypes $(\mathrm{S} / 1, \mathrm{~S} / 1$, for example) were divided into their cis and trans linkage forms, such as $\mathrm{SS} / 11$ and $\mathrm{S} 1 / 1 \mathrm{~S}$ in the case of $\mathrm{S} / 1, \mathrm{~S} / 1$, the data showed significant departure from equilibrium, especially because of an excess of $3 S$ and deficiency of 31. This effect of the double heterokaryotypes stemmed from significant inequalities in their karyotypes and their component linkage combinations, so that they made the major contribution to the departures from equilibrium in the Blacksburg data, even though the double heterokaryotypes constituted less than $10 \%$ of the population.

If the most prevalent arrangements have the following frequencies:

$\begin{array}{rr}\text { Left S: } \mathrm{a} & \text { Right S: } \mathrm{p} \\ \text { 1: } \mathrm{b} & 1: \mathrm{q} \\ \text { 2: } \mathrm{c} & \\ \text { 3: } \mathrm{d} & \end{array}$

then, at equilibrium, the frequency of the combination $S S$ should be $a p$, that of $S 1 a q, 1 S b p, 11 b q$, etc. The various double heterokaryotypes should have the following frequencies:

$\begin{array}{ll}\mathrm{SS} / 11 & 2 a b p q \\ \mathrm{~S} 1 / 1 \mathrm{~S} & 2 a b p q \\ \mathrm{SS} / 21 & 2 a c p q \\ \mathrm{~S} 1 / 2 \mathrm{~S} & 2 a c p q \\ \mathrm{SS} / 31 & 2 a d p q \\ \mathrm{~S} 1 / 3 \mathrm{~S} & 2 a d p q, \text { etc. }\end{array}$

At equilibrium, the frequencies of cis and trans forms of the double heterokaryotes with the same left and right arm arrangements, such as SS/11 and $\mathrm{S} 1 / 1 \mathrm{~S}$, should be equal. Furthermore, in the double heterokaryotypes, the total frequencies of any two combinations with the same left arm arrangement should be equal. For instance, the total frequency of combinations $S S$ and $S 1$ are:

$$
S S=a b p q+a c p q+a d p q=a p q(b+c+d),
$$

and

$$
S 1=a b p q+a c p q+a d p q=a p q(b+c+d) .
$$

Because equalities are being tested, not the specific numbers of the combinations, and because the sums of equalities are also equalities, it is possible to combine data from many localities and samples of different sizes irrespective of differences in arrangement frequencies.

The data for this report come from 161 populations collected from 1946 to 1996 . Those described by Levitan (1992) are supplemented by additional results of Levitan \& Etges (1995) from several localities in Arkansas, by recent data from Englewood and Paramus, NJ, Ithaca and Riverhead, NY, and Philadelphia, PA, and by a Blacksburg, VA, sample of 92 that was accidentally omitted in compiling 
table 26 of Levitan (1992). Omitted are combinations involving rarer gene arrangements, including the 646 observed at $>46^{\circ} \mathrm{N}$, where four of the common combinations are missing, and much of the polymorphism involves arrangements, probably of recent origin, endemic to the area.

Significance of deviations from equality is based on probability tables for 1:1 Mendelian ratios published by Warwick (1932) for samples of 50 or fewer, chi-squared tests with one degree of freedom for samples of 51 or more.

\section{Results}

We compared the numbers of the eight linkage combinations in second chromosome double heterokaryotypes in the southern United States (Table 1) and the northern part of the range (Table 2).

Table 1 Linkage combinations in D. robusta heterozygous for gene arrangements in both arms of chromosome 2 in various regions of the southern United States

\begin{tabular}{|c|c|c|c|c|c|c|c|c|c|c|c|c|c|c|}
\hline Area & Sample & $S S$ & & S1 & $1 S$ & & 11 & $2 S$ & & 21 & $3 S$ & & 31 & Total \\
\hline $\begin{array}{l}\text { Smoky-Unaka Mountains, } \\
\text { TN, NC }\end{array}$ & $\begin{array}{l}\text { Males } \\
\text { Females } \\
\text { Both }\end{array}$ & $\begin{array}{r}8 \\
9 \\
17\end{array}$ & $*$ & $\begin{array}{l}15 \\
16 \\
31\end{array}$ & $\begin{array}{r}9 \\
10 \\
19\end{array}$ & * & $\begin{array}{l}20 \\
17 \\
37\end{array}$ & $\begin{array}{l}4 \\
5 \\
9\end{array}$ & & $\begin{array}{r}5 \\
6 \\
11\end{array}$ & $\begin{array}{l}32 \\
27 \\
59\end{array}$ & $\begin{array}{l}* * \\
* * \\
* *\end{array}$ & $\begin{array}{l}13 \\
12 \\
25\end{array}$ & $\begin{array}{l}106 \\
102 \\
208\end{array}$ \\
\hline Alleghenies, VA, WV, $\mathrm{PA} \dagger$ & $\begin{array}{l}\text { Males } \\
\text { Females } \\
\text { Both }\end{array}$ & $\begin{array}{l}34 \\
30 \\
64\end{array}$ & $\begin{array}{l}* * \\
*\end{array}$ & $\begin{array}{l}63 \\
29 \\
92\end{array}$ & $\begin{array}{l}34 \\
18 \\
52\end{array}$ & $\begin{array}{l}* \\
* \\
* *\end{array}$ & $\begin{array}{l}58 \\
28 \\
82\end{array}$ & $\begin{array}{l}30 \\
20 \\
50\end{array}$ & & $\begin{array}{l}34 \\
20 \\
54\end{array}$ & $\begin{array}{r}76 \\
40 \\
116\end{array}$ & $\begin{array}{l}* * \\
* *\end{array}$ & $\begin{array}{l}29 \\
31 \\
60\end{array}$ & $\begin{array}{l}358 \\
216 \\
574\end{array}$ \\
\hline $\begin{array}{l}\text { NC, GA Blue Ridge } \\
\text { Mountains }\end{array}$ & $\begin{array}{l}\text { Males } \\
\text { Females } \\
\text { Both }\end{array}$ & $\begin{array}{l}8 \\
0 \\
8\end{array}$ & * & $\begin{array}{l}2 \\
2 \\
4\end{array}$ & $\begin{array}{l}5 \\
2 \\
7\end{array}$ & & $\begin{array}{r}10 \\
2 \\
12\end{array}$ & $\begin{array}{l}4 \\
3 \\
7\end{array}$ & & $\begin{array}{r}10 \\
2 \\
12\end{array}$ & $\begin{array}{r}11 \\
3 \\
14\end{array}$ & & $\begin{array}{l}6 \\
2 \\
8\end{array}$ & $\begin{array}{l}56 \\
16 \\
72\end{array}$ \\
\hline $\begin{array}{l}\text { Subtotal: areas with } \\
2 \mathrm{~L}-3>25 \%\end{array}$ & $\begin{array}{l}\text { Males } \\
\text { Females } \\
\text { Both }\end{array}$ & $\begin{array}{l}50 \\
39 \\
89\end{array}$ & $\begin{array}{l}* * \\
* *\end{array}$ & $\begin{array}{r}80 \\
47 \\
127\end{array}$ & $\begin{array}{l}48 \\
30 \\
78\end{array}$ & $\begin{array}{l}* * \\
* *\end{array}$ & $\begin{array}{r}88 \\
47 \\
135\end{array}$ & $\begin{array}{l}38 \\
28 \\
66\end{array}$ & & $\begin{array}{l}49 \\
28 \\
77\end{array}$ & $\begin{array}{r}119 \\
70 \\
189\end{array}$ & $\begin{array}{c}* * \\
* \\
* *\end{array}$ & $\begin{array}{l}48 \\
45 \\
93\end{array}$ & $\begin{array}{l}520 \\
334 \\
854\end{array}$ \\
\hline VA-GA Piedmont & $\begin{array}{l}\text { Males } \\
\text { Females } \\
\text { Both }\end{array}$ & $\begin{array}{l}15 \\
13 \\
28\end{array}$ & & $\begin{array}{l}15 \\
14 \\
29\end{array}$ & $\begin{array}{l}17 \\
13 \\
30\end{array}$ & * & $\begin{array}{l}28 \\
18 \\
46\end{array}$ & $\begin{array}{r}16 \\
7 \\
23\end{array}$ & & $\begin{array}{r}14 \\
8 \\
22\end{array}$ & $\begin{array}{l}11 \\
11 \\
22\end{array}$ & $\begin{array}{c}* * \\
* \\
* *\end{array}$ & $\begin{array}{l}2 \\
4 \\
6\end{array}$ & $\begin{array}{r}118 \\
88 \\
206\end{array}$ \\
\hline South-eastern lowlands & $\begin{array}{l}\text { Males } \\
\text { Females } \\
\text { Both }\end{array}$ & $\begin{array}{l}15 \\
10 \\
25\end{array}$ & $\begin{array}{l}* * \\
* *\end{array}$ & $\begin{array}{l}4 \\
4 \\
8\end{array}$ & $\begin{array}{r}6 \\
4 \\
10\end{array}$ & $\begin{array}{l}* * \\
* * \\
* *\end{array}$ & $\begin{array}{l}32 \\
18 \\
50\end{array}$ & $\begin{array}{r}13 \\
9 \\
22\end{array}$ & $\begin{array}{l}* \\
* *\end{array}$ & $\begin{array}{l}4 \\
3 \\
7\end{array}$ & $\begin{array}{l}6 \\
3 \\
9\end{array}$ & * & $\begin{array}{l}0 \\
1 \\
1\end{array}$ & $\begin{array}{r}80 \\
52 \\
132\end{array}$ \\
\hline Ozark and Ouachita regions & $\begin{array}{l}\text { Males } \\
\text { Females } \\
\text { Both } \ddagger\end{array}$ & $\begin{array}{l}33 \\
30 \\
66\end{array}$ & $\begin{array}{l}* \\
*\end{array}$ & $\begin{array}{l}23 \\
17 \\
41\end{array}$ & $\begin{array}{l}23 \\
25 \\
48\end{array}$ & $* *$ & $\begin{array}{l}38 \\
40 \\
80\end{array}$ & $\begin{array}{l}14 \\
11 \\
26\end{array}$ & & $\begin{array}{l}14 \\
13 \\
28\end{array}$ & $\begin{array}{r}5 \\
5 \\
10\end{array}$ & * & $\begin{array}{l}0 \\
1 \\
1\end{array}$ & $\begin{array}{l}150 \\
142 \\
300\end{array}$ \\
\hline North-Central MO & $\begin{array}{l}\text { Males } \\
\text { Females } \\
\text { Both } \ddagger\end{array}$ & $\begin{array}{r}14 \\
3 \\
17\end{array}$ & $\begin{array}{c}* \\
* \\
* *\end{array}$ & $\begin{array}{l}24 \\
10 \\
37\end{array}$ & $\begin{array}{l}21 \\
10 \\
34\end{array}$ & * & $\begin{array}{r}15 \\
3 \\
18\end{array}$ & $\begin{array}{l}5 \\
3 \\
8\end{array}$ & & $\begin{array}{l}1 \\
4 \\
5\end{array}$ & $\begin{array}{l}0 \\
1 \\
1\end{array}$ & & $\begin{array}{l}0 \\
0 \\
0\end{array}$ & $\begin{array}{r}80 \\
34 \\
120\end{array}$ \\
\hline $\begin{array}{l}\text { Subtotal: areas with } \\
2 \mathrm{~L}-3<25 \%\end{array}$ & $\begin{array}{l}\text { Males } \\
\text { Females } \\
\text { Both } \ddagger\end{array}$ & $\begin{array}{r}77 \\
56 \\
136\end{array}$ & & $\begin{array}{r}66 \\
45 \\
112\end{array}$ & $\begin{array}{r}67 \\
52 \\
119\end{array}$ & $\begin{array}{l}* * \\
* \\
* *\end{array}$ & $\begin{array}{r}113 \\
79 \\
194\end{array}$ & $\begin{array}{l}48 \\
30 \\
79\end{array}$ & & $\begin{array}{l}33 \\
28 \\
62\end{array}$ & $\begin{array}{l}22 \\
20 \\
42\end{array}$ & $\begin{array}{l}* * \\
* * \\
* *\end{array}$ & $\begin{array}{l}2 \\
6 \\
8\end{array}$ & $\begin{array}{l}428 \\
316 \\
752\end{array}$ \\
\hline Total: southern populations & $\begin{array}{l}\text { Males } \\
\text { Females } \\
\text { Both } \ddagger\end{array}$ & $\begin{array}{r}127 \\
95 \\
225\end{array}$ & & $\begin{array}{r}146 \\
92 \\
239\end{array}$ & $\begin{array}{r}115 \\
82 \\
197\end{array}$ & $\begin{array}{l}* * \\
* * \\
* *\end{array}$ & $\begin{array}{l}201 \\
126 \\
329\end{array}$ & $\begin{array}{r}86 \\
58 \\
145\end{array}$ & & $\begin{array}{r}82 \\
56 \\
139\end{array}$ & $\begin{array}{r}141 \\
90 \\
231\end{array}$ & $\begin{array}{l}* * \\
* * \\
* *\end{array}$ & $\begin{array}{r}50 \\
51 \\
101\end{array}$ & $\begin{array}{r}948 \\
650 \\
1606\end{array}$ \\
\hline
\end{tabular}

Asterisks denote the pairs of combinations with the same left arm arrangements that deviate significantly from the equality that would be expected in each case on the assumption of linkage equilibrium.

${ }^{*} P<0.05,{ }^{*} P<0.01$.

$\dagger$ Includes a few data from the Alleghenies of western Pennsylvania.

†ncludes data from crosses of wild males to wild females in which it could not be determined which gender was the double heterokaryote. 
The north-south division is generally based on the standard terminology, the boundary being Mason and Dixon's line $\left(39^{\circ} 43^{\prime} 26.3^{\prime \prime} \mathrm{N}\right.$, between Pennsylva- nia and Maryland and part of west Virginia), the Ohio River and the Missouri-Illinois, MissouriIowa and Nebraska-Kansas borders. Although this

Table 2 Linkage combinations in D. robusta heterozygous for gene arrangements in both arms of chromosome 2 in various regions of the northern United States

\begin{tabular}{|c|c|c|c|c|c|c|c|c|c|c|c|c|c|c|}
\hline Area & Sample & $S S$ & & $S 1$ & $1 S$ & & 11 & $2 S$ & & 21 & $3 S$ & & 31 & Total \\
\hline \multirow[t]{3}{*}{ Iowa, Nebraska } & Males & 2 & & 7 & 1 & & 5 & 2 & & 1 & 8 & $* *$ & 0 & 26 \\
\hline & Females & 0 & $*$ & 5 & 3 & & 1 & 0 & & 0 & 3 & & 0 & 12 \\
\hline & Both & 2 & $* *$ & 12 & 4 & & 6 & 2 & & 1 & 11 & $* *$ & 0 & 38 \\
\hline \multirow[t]{3}{*}{ NE Indiana, SE Michigan } & Males & 2 & $*$ & 8 & 0 & & 3 & 3 & & 3 & 10 & $* *$ & 1 & 30 \\
\hline & Females & 3 & & 2 & 0 & & 0 & 0 & & 1 & 2 & & 2 & 10 \\
\hline & Both & 5 & & 10 & 0 & & 3 & 3 & & 4 & 12 & * & 3 & 40 \\
\hline \multirow{3}{*}{$\begin{array}{l}\text { NY, NJ and PA with } \\
2 \mathrm{~L}-3>25 \%\end{array}$} & Males & 15 & & 11 & 4 & & 7 & 1 & & 3 & 10 & & 9 & 60 \\
\hline & Females & 9 & & 5 & 8 & & 8 & 1 & & 0 & 5 & & 10 & 46 \\
\hline & Both & 24 & & 16 & 12 & & 15 & 2 & & 3 & 15 & & 19 & 106 \\
\hline Subtotal: areas with & Males & 19 & & 26 & 5 & $*$ & 15 & 6 & & 7 & 28 & $* *$ & 10 & 116 \\
\hline \multirow[t]{2}{*}{$2 \mathrm{~L}-3>25 \%$} & Females & 12 & & 12 & 11 & & 9 & 1 & & 1 & 10 & & 12 & 68 \\
\hline & Both & 31 & & 38 & 16 & & 24 & 7 & & 8 & 38 & $*$ & 22 & 184 \\
\hline \multirow[t]{3}{*}{ Lake Plains, $\mathrm{OH}$} & Males & 17 & & 14 & 8 & & 12 & 3 & & 6 & 9 & & 5 & 74 \\
\hline & Females & 12 & & 10 & 5 & & 8 & 2 & & 1 & 5 & & 5 & 48 \\
\hline & Both & 29 & & 24 & 13 & & 20 & 5 & & 7 & 14 & & 10 & 122 \\
\hline \multirow[t]{3}{*}{ SE NY, NE NJ } & Males & 8 & & 15 & 18 & * & 8 & 0 & & 0 & 4 & & 7 & 60 \\
\hline & Females & 8 & & 5 & 6 & & 5 & 0 & & 0 & 1 & * & 7 & 32 \\
\hline & Both & 16 & & 20 & 24 & $*$ & 13 & 0 & & 0 & 5 & $*$ & 14 & 92 \\
\hline \multirow[t]{3}{*}{ Southern NJ, SE PA } & Males & 19 & & 17 & 11 & $*$ & 22 & 6 & & 1 & 8 & & 4 & 88 \\
\hline & Females & 15 & $*$ & 7 & 6 & * & 14 & 4 & & 1 & 1 & & 4 & 52 \\
\hline & Both & 34 & & 24 & 17 & $* *$ & 36 & 10 & $*$ & 2 & 9 & & 8 & 130 \\
\hline \multirow[t]{3}{*}{ Southern Indiana } & Males & 30 & & 32 & 26 & & 26 & 8 & & 9 & 6 & & 3 & 140 \\
\hline & Females & 40 & $* *$ & 20 & 17 & $*$ & 29 & 5 & & 12 & 2 & & 3 & 128 \\
\hline & Both & 70 & & 52 & 43 & & 55 & 13 & & 21 & 8 & & 6 & 268 \\
\hline \multirow[t]{3}{*}{ South-central $\mathrm{OH} \dagger$} & Males & 16 & & 19 & 13 & & 10 & 3 & & 4 & 5 & & 4 & 74 \\
\hline & Females & 8 & * & 16 & 9 & & 7 & 5 & & 2 & 5 & & 2 & 54 \\
\hline & Both & 24 & & 35 & 22 & & 17 & 8 & & 6 & 10 & & 6 & 128 \\
\hline \multirow{3}{*}{$\begin{array}{l}\text { Subtotal: areas with } \\
2 \mathrm{~L}-3<25 \%\end{array}$} & Males & 90 & & 97 & 76 & & 78 & 20 & & 20 & 32 & & 23 & 436 \\
\hline & Females & 83 & $*$ & 58 & 43 & & 63 & 16 & & 16 & 14 & & 21 & 314 \\
\hline & Both & 173 & & 155 & 119 & & 141 & 36 & & 36 & 46 & & 44 & 750 \\
\hline \multirow[t]{3}{*}{ Total: northern populations } & Males & 109 & & 123 & 81 & & 93 & 26 & & 27 & 60 & $* *$ & 33 & 552 \\
\hline & Females & 95 & & 70 & 54 & & 72 & 17 & & 17 & 24 & & 33 & 382 \\
\hline & Both & 204 & & 193 & 135 & & 165 & 43 & & 44 & 84 & & 66 & 934 \\
\hline
\end{tabular}

Asterisks denote the pairs of combinations with the same left arm arrangements that deviate significantly from the equality that would be expected in each case on the assumption of linkage equilibrium.

$* P<0.05,{ }^{* *} P<0.01$.

$\dagger$ Includes a few data from northern Kentucky that are combined with those from nearby Ohio. 
boundary line is not based on biological considerations, it is very near to the boundaries between areas devastated by the Pleistocene glaciations and the refugia from which many organisms, probably including $D$. robusta, repopulated these areas. Levitan (1992) noted that, in many longitudinal transects, this is the approximate latitudinal level at which the frequencies of some of the northern gene arrangements first make significant appearances at low elevations (e.g. XL-1 and 2L-3) and at which some of the southern arrangements become quite rare (e.g. $2 \mathrm{~L}-2$ and $2 \mathrm{R}-1$ ). It will be seen, furthermore, that many critical differences arise in the present data at this latitudinal level. However, a sample from Lexington, KY, slightly south of the Ohio River, is included in the northern group, because its arrangement frequencies are more similar to those of nearby Ohio than to any southern locality studied, and a high elevation sample from Mt Lebanon, PA, fits better with the nearby southern Allegheny data than with any northern area studied.

Significant inequalities of second chromosome combinations with the same left arm arrangement are very common in the double heterokaryotypes of southern populations (Table 1). As at Blacksburg, the inequalities are most prominent in the males and in the differences between the numbers of $3 S$ and 31 . Not only are significant inequalities rarer in the female double heterokaryotypes, but almost all those that attain statistical significance do so at a lower level than males with the same combinations. Deviations from equality are particularly strong in areas with more than 25\% 2L-3 because of the large amount of data from the Smoky/Unaka Mountains in the southern Appalachians and the Alleghenies of Virginia, west Virginia and nearby Pennsylvania. Excesses of $3 S$ over 31 are present in every Table 1 sample except north-central Missouri, where 2L-3 is very rare, and they are highly significant in the total data from the areas with less than $25 \% 2 \mathrm{~L}-3$ as well as the areas with more.

At Blacksburg (Levitan, 1955; unpubl. data), the difference between $3 S$ and 31 in the double heterokaryotypes, 51 (105-54), was almost exactly the same as the excess of $3 S$ (and concomitant deficiency of 31) in the complete data set from that locality, 52.9. Similarly, the inequalities between $S S$ and $S 1$ and those between $1 S$ and 11 accounted for almost all the discrepancies in those combinations in the overall data. On the other hand, the absence of significant inequalities between $2 S$ and 21 in the double heterokaryotypes was reflected in the close fit of those combinations to expected values in the overall data. Thus, the frequencies of particular second chromosome gene arrangement combinations in this population were influenced by natural selection acting at the level of the whole second chromosome karyotype.

Our southern data follow a similar pattern for the most part. The total excess of $3 S$ over 31 in the double heterokaryotypes in Table 1 is 130. Adding the Levitan (1992) results for all second chromosome karyotypes from the lowland areas south of the north-south boundaries and those from the Appalachians (also southern), the deficiency of 31 from the number expected under linkage equilibrium (and the corresponding excess of $3 S$ ) is 146.2 (observed $=306, \quad$ expected $=452.2$ ). Thus the discrepancy between these combinations in the double heterokaryotypes accounts for about $90 \%$ of their contribution to the overall linkage disequilibrium in this region. The percentage is even higher for the $1 S-11$ pair, where the total difference between the two among the double heterokaryotypes (Table 1) is 132, and the deviations from expected among all karyotypes (Levitan, 1992) is 130.5. The $S S-S 1$ pair, on the other hand, does not derive its major Table 1 deviations from linkage equilibrium from the discrepancies in the double heterozygotes, contrary to pattern, because the frequency of $S S$ exceeds random expectation (and $S 1$ below), or they are nearly equal, in several southern areas.

The many significant deviations from the linkage equilibrium equalities, even in areas with less than $25 \% 2 \mathrm{~L}-3$, are particularly noteworthy, because many of these areas, possessing relatively large amounts of 2R-1, have some of the highest rates of second chromosome double heterozygosity. For example, close to one-third of the fully analysed adults from Raleigh, NC were second chromosome double heterokaryotypes. (The theoretical maximum for four 'alleles' on one arm and two on the other is $37.5 \%$.) These southern areas are also interesting because they exhibit several deviations from typical patterns: the above-mentioned excess of $S S$ over $S 1$ in several areas; in one area $2 S$ vs. 21 has a significant inequality; and in north-central Missouri, two of the three significant inequalities are in the females and $1 S$ is significantly more common than 11 . The last point is also reflected in Levitan (1992) in that the south-western portion of the data at $37-39.59^{\circ} \mathrm{N}$ latitude contains a significant excess of $1 S$ and deficiency of $1 I$.

Although one of the critical left arm arrangements, $2 \mathrm{~L}-3$, is more common there than in the south, populations in the northern part of the range (Table 2) contain fewer data than the southern part, 
because $2 \mathrm{R}-1$ is more common in the south, falling to less than $10 \%$ at approximately $38^{\circ} \mathrm{N}$ and completely absent in many more northern samples (Carson, 1958; Levitan, 1992). Furthermore, many of the southern data come from its higher elevations, where both $2 \mathrm{~L}-3$ and $2 \mathrm{R}-1$ exist at frequencies that give rise to numerous double heterokaryotypes (Levitan \& Scheffer, 1993).

Despite the relative paucity of double heterokaryotypes, the excess of $3 S$ over 31 is seen in many northern areas as well. Here, it appears exclusively in males. Indeed, the one significant deviation from equality among females doubly heterozygous for 2L-3 karyotypes, in south-eastern New York and north-eastern New Jersey, is the reverse of the usual pattern: 31 has the greater frequency. The excess of $3 S$ over 31 in northern male double heterokaryotypes plays a much smaller part, however, in the overall discrepancies of these combinations from equilibrium expectations than it does in the south, the excess in the northern males accounting for less than a third of the deviations among all 2L-3 karyotypes.

The southern New Jersey-SE Pennsylvania region double heterokaryotypes in both genders are similar to the southern pattern in their significant excess of 11 over $1 \mathrm{~S}$, as are southern Indiana females. However, a reverse of this pattern is significant in south-eastern New York and north-eastern New Jersey males, and there were enough samples that are equivocal in this regard that the northern US totals for this combination pair, although containing more 11 than $1 S$, are not statistically significant. Moreover, their direction in the double heterokaryotypes is the opposite from that in the overall northern data in Levitan (1992), where $1 S$ is in excess of random expectation (although not at a statistically significant level) and 11 deficient.

In the Levitan (1992) data, the northern populations in all 2L karyotypes have significant excesses of $S 1$ and deficiencies of $S S$, the southern pattern, to counterbalance the excesses of $3 S$ and deficiency of 31 , but, as with the $3 S-31$ pair, this cannot be adequately accounted for by the double heterokaryotypes. Two northern areas with more than $25 \%$ $2 \mathrm{~L}-3$ that have the strongest excesses of $3 S$ over 31 in doubly heterokaryotypic males also have some significant excesses of $S 1$ over $S S$ (Table 2); however, a reversal of these trends in a third area results in none of the subtotals for $S S$ and $S 1$ in areas with $2 \mathrm{~L}-3>25 \%$ being significant. Furthermore, in two northern areas with fewer $2 \mathrm{~L}-3$ and in the subtotal for areas with fewer than $25 \%$ 2L-3, the female double heterokaryotypes have significant excesses of $S S$ rather than $S 1$, resembling the contrary results in several southern localities with less than $25 \% 2 \mathrm{~L}-3$.

\section{Discussion}

Linkage disequilibrium of the second chrosomosome gene arrangements in natural populations of $D$. robusta is widespread. In many localities, particularly among males in the southern U.S. the major factors producing disequilibrium are inequalities between the cis and trans forms of double heterokaryotypes and their component linkage combinations (or haplotypes). Despite the long interest in understanding the factors that maintain inversion polymorphism in natural populations indicated by the huge empirical literature spanning the last 60 years (Krimbas \& Powell, 1992), maintenance of linkage disequilibrium of inversion through selection on particular whole chromosome karyotypes of the kind described here for natural populations of D. robusta is unique. This form of selection, although interesting on its own, may not provide much insight into the general mechanisms thought to preserve inversion polymorphisms, because it involves particular kinds of heterokaryotypes, suggesting complex dominance/epistatic interactions between particular homologues generating linkage disequilibrium. Nothing is known of the sorts of alleles within gene arrangements on either end of chromosome 2 that may be involved in this type of selection in $D$. robusta.

Levitan (1958b) surveyed a large number of Drosophila species for the distribution of inversion polymorphism and found a lack of fit to a Poisson distribution,suggesting a non-random distribution of inversion polymorphism across species. Many species lack inversion polymorphism altogether, e.g. many of the homosequential Hawaiian Drosophila (Carson et al., 1967) and almost half of the large repleta group (Wasserman, 1992). This pattern is not consistent with a mutation-accumulation hypothesis, in which younger species might be expected to possess less polymorphism, as many of the most derived species possess rich inversion polymorphism, e.g. D. silvestris on the youngest of the Hawaiian islands (Craddock \& Carson, 1989), D. mojavensis and D. pachea from the Sonoran Desert (Etges et al., 1998) and D. parisiena from several Caribbean islands (Wasserman \& Wasserman, 1992).

The great varety of inversion polymorphisms across species or species groups and even within the same genus or subgenus suggests a shared, recurring form of adaptation to either the ambient environ- 
ment or, in the case of known associations with differences in mating success, the sexual environment (Carson, 1987; Salceda \& Anderson, 1988; Etges, 1996). In this connection, this study emphasizes a point that is generally overlooked when considering the value of work on chromosomal polymorphism: the Drosophila species that have been studied extensively have developed a number of very different systems of inversion polymorphism. In $D$. pseudoobscura and its relatives (reviewed by Powell, 1992), the primary mechanism is a series of overlapping inversions on one autosome, whereas in another member of the obscura group, D. subobscura, inhabiting for the most part a different part of the world, all chromosome arms are highly polymorphic (reviewed by Krimbas, 1992). Within the broadly cosmopolitan $D$. melanogaster, several gene arrangements have worldwide distributions with many rare, endemic inversions known only in local populations; however, the sibling species, D. simulans, lacks inversion polymorphism except for a few rare gene arrangements (Lemeunier \& Aulard, 1992). Our data emphasize the differential frequencies of cis and trans double heterokaryotypes as the unique way that $D$. robusta second chromosome inversion polymorphism has evolved, along with three different forms of $\mathrm{X}$ chromosome disequilibrium (Levitan, 1992; Levitan \& Etges, 1995).

It remains to be determined from more extensive study if any of the 49 other species with well established or presumptive non-random associations of inversions (Levitan \& Fukatami, 1993) follow the $D$. robusta second chromosome pattern. The best candidate appears to be D. subobscura, in which the A chromosome (its sex chromosome) presents a disequilibrium reminiscent of the XL-2.XR-2 association in D. robusta, and the autosome with the largest number of inversions presents at least 11 associations among its non-overlapping ones (Krimbas, 1992). Unlike the D. robusta situation, however, apparently no recombination occurs between these inversions in the double heterozygotes, despite the availability of ample genetic distance in many cases. Among the 'presumptives' on the list are the South and Central American sibling species, D. willistoni and D. paulistorum, which are very interesting because of their large amount of multiarm inversion polymorphism (Dobzhansky \& Powell, 1975; Valiati \& Valente, 1997); indeed D. paulistorum, with 99 known inversions, probably has the largest number of such variations known. Because these species are so difficult cytologically, the quantitative relations among their inversions are unknown, but the two, albeit sibling species, also exhibit different patterns: more than half of the inversions of $D$. paulistorum are in one autosome, and the chromosomal polymorphism is bound up with a complex system of subspeciation (Dobzhansky \& Powell, 1975), whereas neither condition is true in its sibling species.

In no case, however, has there been revealed a mechanistic basis for how natural or sexual selection operates on those sets of genes frozen together within inversions. Dobzhansky (1949) held the view that 'the biological significance of inversions is that they build together, and hence prevent breakdown by crossing-over, groups of polygenes which possess high adaptive values'. Whether selection is operating directly on these polygenes in an epistatic fashion or on groups of loci between inversions in heterokaryotypes in a heterotic manner, a view that Dobzhansky held throughout most of his career, these polygenes remain to be identified and, in many cases, it is not clear what form of selection is operating. In the non-random associations of inversions, there is often the additional problem that crossingover does occur between the linked inversions, yet there is evidence in the D. robusta situation at least that the various disequilibria are maintained by selection in a variety of ways (Levitan \& Etges, 1995). Although further documentation of the selective maintenance of inversion polymorphism in Dipteran natural populations is of interest to students of natural and sexual selection, it does not answer the prime question of what sets of alleles within gene arrangements are the targets of selection. The diversity of inversion polymorphisms and the large role they have played in our understanding of the evolutionary process make answering this question an urgent priority in future investigations.

\section{Acknow ledgements}

M. L. is grateful to the Myron M. Kaplan Charitable Foundation for support while obtaining the most recent data, to the National Science Foundation for several grants that were responsible for earlier data, and to D. J. Begun for sending him flies collected at Ithaca, NY. W. J. E. wishes to thank D. White and A. Badyaev for their assistance in the Arkansas collections, and he is grateful for support from the Department of Biological Sciences of the University of Arkansas.

\section{References}

CARSON, H. L. 1958. The population genetics of Drosophila robusta. Adv. Genet., 9, 1-40.

(c) The Genetical Society of Great Britain, Heredity, 80, 660-667. 
CARSON, H. L. 1987. High fitness of karyotypic individuals segregating naturally within a long-standing laboratory population of Drosophila silvestris. Genetics, 116, 415-422.

CARSON, H. L., ClAyton, F. E. AND StAlKer, H. D. 1967. Karyotypic stability and speciation in Hawaiian Drosophila. Proc. Natl. Acad. Sci. U.S.A., 57, 1280-1285.

CARSON, H. L. AND STALKER, H. D. 1947. Gene arrangements in natural populations of Drosophila robusta Sturtevant. Evolution, 1, 113-133.

CRADDOCK, E. M. AND CARSON, H. L. 1989. Chromosome inversion patterning and population differentiation in a young insular species, Drosophila silvestris. Proc. Natl. Acad. Sci. U.S.A., 86, 4798-4802.

DOBZHANSKY, TH. 1949. On some of the problems of population genetics and evolution. In: Symposium sui Fattori Ecologici della Speciazione negli Animali. La Ricerca Scientifica, 19 (Suppl.), 11-17.

DOBZHANSKY, TH. AND POWELL, J. R. 1975. The willistoni group of sibling species of Drosophila. In: King, R. C. (ed.) Handbook of Genetics, pp. 589-622. Plenum Press, New York.

ETGES, w. J. 1984. Genetic structure and change in natural populations of Drosophila robusta: systematic inversion and inversion association frequency shifts in the Great Smoky Mountains. Evolution, 38, 675-688.

ETGES, w. J. 1996. Sexual selection operating in a wild population of Drosophila robusta. Evolution, 50, 2095-2100.

ETGES, W. J., JOHNSON, W. R. DUNCAN, G. A., HUCKINS, G. AND HEED, w. B. 1998. Ecological genetics ofcactophilic Drosophila. In: Robichaux, R. (ed.) Ecology of Sonoran Desert Plants and Plant Communities. University of Arizona Press, Tucson, AZ (in press).

GEIRINGER, H. 1944. On the probability theory of linkage in Mendelian heredity. Ann. Math. Stat., 15, 25-57.

GEIRINGER, H. 1948. On the mathematics of random mating in case of different recombination values for males and females. Genetics, 33, 548-564.

KRIMBAS, C. B. 1992. The inversion polymorphism of Drosophila subobscura. In: Krimbas, C. B. and Powell, J. R. (eds) Drosophila Inversion Polymorphism, pp. 127-220. CRC Press, Boca Raton, FL.

KRIMBAS, C. B. AND POWEll, J. R.. (eds) Drosophila Inversion Polymorphism. CRC Press, Boca Raton, FL.

LEMEUNIER, F. AND AULARD, s. 1992. Inversion polymorphism in Drosophila melanogaster. In: Krimbas, C. B. and Powell, J. R. (eds) Drosophila Inversion Polymorphism, pp. 339-405. CRC Press, Boca Raton, FL.

LEVITAN, M. 1955. Studies of linkage in populations. I. Associations of second chromosome inversions in Drosophila robusta. Evolution, 9, 62-75.

LEVITAN, M. 1958a. Studies of linkage in populations. II. Recombination between inversions in Drosophila robusta. Genetics, 43, 602-633.
LEVITAN, M. 1958b. Non-random associations of inversions. Cold Spring Harb. Symp. Quant. Biol., 23, 251-268.

LEVITAN, M. 1973. Studies of linkage in populations. VI. Periodic selection for X-chromosome gene arrangement combinations. Evolution, 27, 215-225.

LEVITAN, M. 1978. Studies of linkage in populations. IX. The effect of altitude on X-chromosomal arrangement combinations in Drosophila robusta. Genetics, 89, 751-763.

LevitAn, M. 1992. Chromosomal variation in Drosophila robusta Sturtevant. In: Krimbas, C.B. and Powell, J.R. (eds) Drosophila Inversion Polymorphism, pp. 221-338. CRC Press, Boca Raton, FL.

LEvitan, M. AND ETGES, W. J. 1995. Convergent linkage disequilibrium in disparate populations of Drosophila robusta. In: Levine, L. (ed.) Genetics of Natural Populations: The Continuing Importance of Theodosius Dobzhansky, pp. 105-119. Columbia University Press, New York.

LEVITAN, M. AND FUKATAMI, A. 1993. Studies of linkage in populations. XI. Overlooked associations of inversions in two species, with a review of the prevalence of the phenomenon. Evolucion Biologica, 7, 105-132.

LEVITAN, M. AND SCHEFFER, S. J. 1993. Studies of linkage in populations. X. Altitude and autosomal gene arrangements in Drosophila robusta. Genet. Res., 61, 9-20.

POWELL, J. R. 1992. Inversion polymorphisms in Drosophila pseudoobscura and Drosophila persimilis. In: Krimbas, C. B. and Powell, J. R. (eds) Drosophila Inversion Polymorphism, pp. 73-126. CRC Press, Boca Raton, FL.

ROBBINS, R. B. 1918. Some applications of mathematics to breeding problems. III. Genetics, 3, 375-389.

SAlCEDA, v. M. AND ANDERSON, w. w. 1988. Rare male mating advantage in a natural population of Drosophila pseudoobscura. Proc. Natl. Acad. Sci. U.S.A., 85, 9870-9874.

TURElli, M., ClARK, A. G. AND SPOFFORD, J. B. 1984. Linkage data supporting a mathematical explanation for some empirical cis-trans effects. Heredity, 52, $145-147$.

VAliAti, V. H. AND VALENTE, v. L. S. 1997. Chromosomal polymorphism in urban populations of Drosophila paulistorum. Brazilian J. Genet., 20, 567-581.

WARWICK, B. L. 1932. Probability tables for Mendelian ratios with small numbers. Texas Agr. Expt. Stn. Bull., 463, 1-28.

WASSERman, M. 1992. Cytological evolution of the Drosophila repleta species group. In: Krimbas, C. B. and Powell, J. R. (eds) Drosophila Inversion Polymorphism, pp. 455-552. CRC Press, Boca Raton, FL.

WASSERMAN, M. AND WASSERMAN, F. 1992. Inversion polymorphism in island species of Drosophila. In: Hecht, M. K., Wallace, B. and MacIntyre, R. J. (eds) Evolutionary Biology, Vol. 26, pp. 351-381. Plenum Press, New York. 